\title{
Amount of Zinc Transferred in Breast Milk to Breastfed Moroccan Babies with Normal or Low Birth Weight at 1, 3 and 6 Months After Birth
}

\author{
Ghizlane Choua ${ }^{1, *}$, Nourddine El Haloui ${ }^{1}$, Khalid El Kari ${ }^{1}$, Hassan Aguenaou ${ }^{1}$ and \\ Najat Mokhtar ${ }^{2}$ \\ ${ }^{1}$ Unité Mixte de Recherche en Nutrition et Alimentation, (Université Ibn Tofail-CNSTEN), URAC 39, Rabat, \\ Morocco \\ ${ }^{2}$ International Atomic Energy Agency, Vienna International Centre, Vienna, Austria
}

\begin{abstract}
The amount of zinc in breast milk is generally regarded as sufficient to cover the increasing zinc demands of most infants. However, this is not well investigated where stores zinc may be compromised in babies with low birth weight (LBW) who are born with low stores of zinc. In Morocco, this is the first time that the amount of zinc transferred in breast milk has been estimated. This study included 32 mother-baby pairs. In our case study, we aimed to measure The quantity of zinc in mothers' breast milk with normal birth weight (NBW) and LBW babies who were exclusively or not exclusively breast fed at 1,3 and 6 month after birth. The results showed that the majority of mothers have a BMI $\geq 25$ $\mathrm{kg} / \mathrm{m}^{2}$ this means that all mothers are overweight during 6 months after birth. Zinc concentration (mg/l) in mothers' breast milk decreased from first month to six month. $\mathrm{p}$ - value showed that for mothers with NBW babies, there is a significant difference between the 1 and 6 month $(p=0.0003)$ and between 3 and 6 month after birth $(p=0.0007)$. For mothers with LBW babies, $p$-value showed a significant difference between the zinc concentration in breast milk in the $1^{\text {st }}$ and $3^{\text {rd }}$ month $(p=0.0007), 1$ and 6 month $(p<0.0001)$ and between $3^{\text {rd }}$ and $6^{\text {th }}$ month after birth $(p=0.0056)$. The rate of NBW babies who were exclusively breastfed was $36.67 \%, 30.25 \%$ and $10 \%$ successively in $1^{\text {st }}, 3^{\text {rd }}$ and $6^{\text {th }}$ month after birth. For LBW babies, the rate of exclusively breastfed was $15.38 \%, 7.69 \%$ and $2.69 \%$ successively in $1^{\text {st }}, 3^{\text {rd }}$ and $6^{\text {th }}$ month after birth. Based on the K. Brown study in 2009, we can develop a mathematical equation to our own population using our data: $\operatorname{Ln}\left[\right.$ Zinc] $=0.960-0.161^{*} \operatorname{Ln}($ âge $)-0.187^{*} \operatorname{Ln}(a ̂ g e)^{2}$. In conclusion the zinc concentration in milk is within normal range and decreases with the age of the babies. The predicted model of zinc concentration in breast milk was developed and tested.
\end{abstract}

Keywords: Zinc in breastmilk, LBW, Exclusive breastfeeding, Model of zinc concentration.

\section{INTRODUCTION}

Adequate zinc nutrition is essential for human health because of zinc's critical structural and functional roles in multiple enzyme systems that are involved in gene expression, cell division, growth, immunologic and reproductive functions [1]. One-third of the world's population lives in very exposed countries with the zinc deficiency [2]. The most vulnerable groups are babies, young children, pregnant women and nursing. This is due to their high need for this essential nutriment [3] The recent Lancet series on maternal and child undernutrition concluded that zinc deficiency is responsible for $\sim 4 \%$ of child mortality and disability-adjusted life-years [4]. In addition, Low birth weight is associated with growth faltering and substantially increasing risk of severe infection-related morbidity and mortality. Impaired zinc status has been reported in small-for-date infants [5]. Breast milk is the only dietary source of zinc for breastfed young infants, and it remains a potentially important source of zinc for older infants and young children who continue

*Address correspondence to this author at the Unité Mixte de Recherche en Nutrition et Alimentation, (Université Ibn Tofail-CNSTEN), URAC 39, Rabat, Morocco; E-mail: chouaghizlane@gmail.com breastfeeding beyond early infancy [6]. The colostrums is very rich in zinc, it is gradually replaced by mature milk, towards the end of the first month of life, the content zinc of the mother's milk becomes very weak and more lactation advances, plus the zinc rates are low in milk. However the needs for growth are accompanied by a significant consumption by zinc during the first year by life [7]. There is very little information on zinc intake from breast milk in infant from developing countries. In Morocco, there is no data on the prevalence of the zinc deficiencies. Furthermore, significant reduction in zinc concentrations during lactation is reported, and it has been postulated that the amount of zinc provided by breast milk may be lower than the Recommended Dietary Allowance (RDA) of zinc [8]. The objective of our study is to estimate the amount of zinc transferred in breast milk to breastfed babies with normal or low birth weight at 1 , 3 and 6 months.

\section{MATERIALS AND METHODS}

\section{Subjects and Study Design}

This investigation is a longitudinal study conducted on 32 mother/baby pairs. Twelve of them were with 
LBW babies and twenty with NBW ones. Women (between 18 and 49 years old) were recruited before the childbirth, during the third antenatal consultation (38 week of amenorrhea), by a pediatric, in the maternity of the children Hospital in Rabat, Morocco. They had similar socioeconomic level without a history of serious disease. They delivered a healthy full-term infant. To include these mothers in this study, they must breastfeed their babies until the sixth month. Mother-infant pairs visited the maternity one month after delivery. We used a questionnaire to collect the data about the mothers and the babies. Mothers' and infants' weight and height were measured. Mothers' breast milk was collected. All these operations were repeated in $3^{\text {rd }}$ and $6^{\text {th }}$ month after childbirth.

\section{Determination the Concentration of Zinc in Mother's Milk}

\section{Collect, Transport and Storage of the Samples}

Collection of the mother's milk samples $(2-4 \mathrm{ml})$ for each participating woman, after washing hands well. Begin nursing infant. Approximately mid-feed (2-3 minutes into the feed), remove infant from breast to collect a sample, by using a car milk or all simply by pressing the breast, to facilitate the rise of milk at $1 \mathrm{st}$, $3^{\text {rd }}$ and the $6^{\text {th }}$ month after the birth. The samples are placed in a kept refrigerator with approximately $-4^{\circ} \mathrm{C}$ and transported to the laboratory. Then aliquots' and stored in the freezer at $-20^{\circ} \mathrm{C}$ until the moment of the analysis.

\section{Preparation of the Sample for the Analysis}

\section{Preparation of the Milk Samples}

After acid washed all the materials to ensure that they are zinc-free. We start by Defrost milk sample and keep warm in water bath. Weigh empty beaker without watch glass. Record weight and label beaker. Vigorously shake milk sample and immediately transfer entire sample into weighed beaker. Weigh beaker and milk sample. Record weight. Cover beaker with watch glass. With each set of samples, prepare internal control standard as above using milk pool. Also include a blank using an empty beaker. Place beaker into

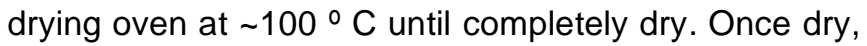
transfer beaker with milk sample into muffle furnace

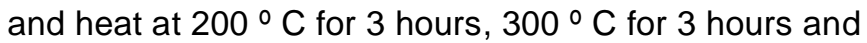
finally for 24 -hours at $450 \circ \mathrm{C}$. Let samples cool and remove from furnace. Add enough concentrated nitric acid to just cover ashes. Place on hot plate at a very low temperature (not boiling) until sample is dry again. Return sample to muffle furnace for 24 hours at $450^{\circ} \mathrm{C}$.

\section{Reconstitution}

Quantitatively reconstitute washed sample with $0.125 \mathrm{~N} \mathrm{HCl}$ by first rinsing the underside of the watch glass and allowing the rinse to fall into the beaker. Aspirate reconstituted sample with a transfer pipette and transfer into a $10 \mathrm{ml}$ volumetric flask. Rinse sides of beaker with another small volume of $0.125 \mathrm{~N} \mathrm{HCl}$. Using transfer pipette, continue to thoroughly rinse the sides of the beaker with a small new volume of $\mathrm{HCl}$. Aspirate and release the $\mathrm{HCl}$ in the beaker a few times, then transfer into volumetric flask. Repeat steps until a volume of exactly $10 \mathrm{ml}$ is reached in the volumetric flask (sample is complete when bottom of liquid meniscus lies atop the white line drawn around the circumference of the flask's neck). Label 14-ml polypropylene test tube (Sarstedt) with subject information (Subject ID, date and time of sample, reconstitution volume). Cap volumetric flask, shake well and immediately pour into labeled test tube. Samples are ready for zinc determination by AAS analyses using standard procedures.

Milk $\mathrm{Zn}$ concentration is calculated with the following equation:

[Milk $\mathrm{Zn}]=\mu \mathrm{g} \mathrm{Zn/dl} \mathrm{(AAS)} \mathrm{*} \mathrm{dl/100} \mathrm{ml} \mathrm{*} \mathrm{dilution} \mathrm{factor} \mathrm{*}$ total reconstitution volume $(\mathrm{ml}) /$ aliquot weight $(\mathrm{g})$

\section{Analyzes}

The zinc content in mother's milk is determined by the technique of analyses per atomic emission: Inductively coupled plasma mass spectrometry «ICPMS», after Quality control process for zinc analysis by in expert for University of Chalmers (Sweden).

\section{Statistical Analyze}

Data were analysed using Epi-info version 6 and MedCalc 11.5.1. software. Independent two sample ttests were used assess the significance of the difference between means. Significance $(p<0.05)$ was determined at the ninety five per cent confidence level.

\section{RESULT}

\section{Mothers Anthropometric Characteristics According to Babies' Age}

Table 1 showed that BMI (Body Mass Index) for mothers with NBW babies $(n=20)$ passes from $26.8 \pm 3.6 \mathrm{~kg} / \mathrm{m}^{2}$ in first month to $25.8 \pm 4.0 \mathrm{~kg} / \mathrm{m}^{2}$ in third month and finally reaches $25.8 \pm 2.6 \mathrm{~kg} / \mathrm{m}^{2}$ at 6 month. 
Table 1: Maternal Anthropometric Characteristics at One, Three, and Six Months Postpartum $(n=32)$

\begin{tabular}{|c|c|c|c|c|c|}
\hline & Babies age & Age (year) & Height (cm) & Weight (Kg) & BMI $\left(\mathrm{kg} / \mathrm{m}^{2}\right)$ \\
\hline \multirow{3}{*}{$\begin{array}{l}\text { Mothers with NBW } \\
\text { babies }(n=20)\end{array}$} & 1 month & \multirow{3}{*}{$28.0 \pm 5.9$} & \multirow{3}{*}{$158.0 \pm 0.05$} & $66.2 \pm 10.9$ & $26.8 \pm 3.6$ \\
\hline & 3month & & & $63.7 \pm 11.2$ & $25.8 \pm 4.0$ \\
\hline & 6 month & & & $63.5 \pm 7.9$ & $25.8 \pm 2.6$ \\
\hline \multirow{3}{*}{$\begin{array}{l}\text { Mothers with LBW } \\
\text { babies }(n=12)\end{array}$} & 1month & \multirow{3}{*}{$25.6 \pm 6.6$} & \multirow{3}{*}{$157.0 \pm 0.05$} & $65.3 \pm 11.2$ & $26.2 \pm 4.5$ \\
\hline & 3month & & & $62.2 \pm 10.7$ & $24.9 \pm 4.2$ \\
\hline & 6 month & & & $63.0 \pm 9.6$ & $25.3 \pm 3.9$ \\
\hline
\end{tabular}

For mothers with LBW babies $(\mathrm{n}=12)$ the BMI passes $26.2 \pm 4.5 \mathrm{~kg} / \mathrm{m}^{2}$ in first month to $24.9 \pm 4.2 \mathrm{~kg} / \mathrm{m}^{2}$ in third month and finally gets to $25.3 \pm 3.9 \mathrm{~kg} / \mathrm{m}^{2}$ at 6 month. The results showed that the majority of mothers have a $\mathrm{BMI} \geq 25 \mathrm{~kg} / \mathrm{m}^{2}$ that means that mothers with LBW or NBW babies are at the beginning limit of overweight during 6 months after birth.

\section{Babies' Anthropometric Characteristics by Age $(n=32)$}

Babies' anthropometric data showed that they did not suffer from any form of malnutrition (Z-scores between -1.43 and 1.13 ) and they grew normally during the six months of the study (Table 2).

\section{Zinc Concentration (mg/l) in Breast Milk for Mothers with NBW and LBW Babies During 6 Month After Birth $(n=32)$}

Zinc concentration $(\mathrm{mg} / \mathrm{l})$ in breast milk for mothers decreased from first month to six month as would be expected in Table 3. For mothers with NBW babies, the zinc concentration in breast milk was $2.674 \pm 1.239 \mathrm{mg} / \mathrm{l}$, $2.037 \pm 0.714 \mathrm{mg} / \mathrm{l}$ and $1.109 \pm 0.474 \mathrm{mg} / \mathrm{l}$ successively in $1^{\text {st }}, 3^{\text {rd }}$ and $6^{\text {th }}$ month after birth. p-value showed a significant difference between the zinc concentration in breast milk between the 1 and 6 month $(p=0.0003)$ and between 3 and 6 month after birth $(p=0.0007)$. As far as mothers with LBW babies, the zinc concentration in breast milk was $2.524 \pm 0.992 \mathrm{mg} / \mathrm{l}, 1.754 \pm 0.673 \mathrm{mg} / \mathrm{l}$ and $1.233 \pm 0.752 \mathrm{mg} / \mathrm{l}$ successively in $1^{\text {st }}, 3^{\text {rd }}$ and $6^{\text {th }}$ month after birth. $p$-value showed a significant difference between the zinc concentration in breast milk in the 1 and 3 month $(p=0.0007), 1$ and 6 month $(p<0.0001)$ and between 3 and 6 month after birth $(p=0.0056)$. However there was no significant difference in breast milk concentration between mothers with NBW babies and mothers with LBW babies in $1^{\text {st }}, 3^{\text {rd }}$ and $6^{\text {th }}$ month after birth.

\section{The Rate of Zinc ( $\mathrm{mg} / \mathrm{l}$ ) in Breast Milk by Mode of Lactation}

After quantifying breast milk and other fluids consumed by infants during the first six months after birth using the isotope stable method [9], we found that the rate of NBW babies who were exclusively breastfed was $36.67 \%, 30.25 \%$ and $10 \%$ successively in $1^{\text {st }}, 3^{\text {rd }}$ and $6^{\text {th }}$ month after birth. For LBW babies, the rate of exclusively breastfed babies was $15.38 \%, 7.69 \%$ and $2.69 \%$ successively in $1^{\text {st }}, 3^{\text {rd }}$ and $6^{\text {th }}$ month after birth.

\section{Zinc Concentration $(\mathrm{mg} / \mathrm{l})$ in Breast Milk for Exclusively Breast Feed Mothers with NBW and LBW Babies During 6 Month After Birth $(n=32)$}

Using the deuterium oxide dose-to-mother technique [9], zinc concentration (mg/l) in breast milk for mothers with NBW babies how exclusively breast

Table 2: Babies' Anthropometric Characteristics by Age $(n=32)$

\begin{tabular}{|c|c|c|c|c|c|c|}
\hline & \multicolumn{3}{|c|}{ Babies with NBW $(\mathrm{n}=\mathbf{2 0})$} & \multicolumn{3}{c|}{ Babies with LBW (n=12) } \\
\hline Babies age (month) & $\mathbf{1}$ & $\mathbf{3}$ & $\mathbf{6}$ & $\mathbf{1}$ & $\mathbf{3}$ \\
\hline \hline Height (cm) & $51.8 \pm 2.5$ & $60.0 \pm 2.1$ & $68.0 \pm 5.4$ & $50.5 \pm 2.7$ & $59.1 \pm 2.9$ & $67.1 \pm 7.9$ \\
\hline Weight (kg) & $4.00 \pm 0.38$ & $5.95 \pm 0.65$ & $7.86 \pm 0.78$ & $3.60 \pm 0.70$ & $5.74 \pm 1.08$ & $7.34 \pm 1.45$ \\
\hline Z-score weight/Lenght & $0.25 \pm 1.20$ & $-0.19 \pm 1.40$ & $-0.05 \pm 1.18$ & $-0.02 \pm 0.57$ & $-0.16 \pm 0.95$ & $-0.53 \pm 1.20$ \\
\hline Z-score weight/Age & $-0.73 \pm 1.31$ & $-0.28 \pm 0.89$ & $0.51 \pm 1.28$ & $-1.43 \pm 1.50$ & $-0.64 \pm 1.21$ & $-0.02 \pm 0.32$ \\
\hline Z-score lenght/Age & $-1.01 \pm 1.27$ & $-0.15 \pm 0.78$ & $1.13 \pm 1.87$ & $-1.61 \pm 1.23$ & $-0.68 \pm 1.41$ & $0.78 \pm 0.84$ \\
\hline Z-score BMl/Age & $-0,29 \pm 0.72$ & $-0.26 \pm 1.07$ & $-0.17 \pm 1.10$ & $-0.82 \pm 1.38$ & $-0.35 \pm 0.65$ & $-0.64 \pm 1.84$ \\
\hline
\end{tabular}


Table 3: Zinc Concentration (mg/l) in Breast Milk for Mothers with NBW and LBW Babies During 6 Month After Birth $(n=32)$

\begin{tabular}{|c|c|c|c|}
\hline \multicolumn{2}{|c|}{ Zinc in breast milk (mg/l) } \\
\hline Babies age & $\begin{array}{c}\text { Mothers with NBW babies } \\
(\mathbf{n = 2 0})\end{array}$ & $\begin{array}{c}\text { Mothers with LBW babies } \\
(\mathbf{n}=\mathbf{1 2})\end{array}$ & $\mathbf{p - v a l u e}$ \\
\hline \hline 1 month & $2.674 \pm 1.239$ & $2.524 \pm 0.992$ & 0.6731 \\
\hline 3 month & $2.037 \pm 0.714$ & $1.754 \pm 0.673$ & 0.2181 \\
\hline 6 month & $1.109 \pm 0.474$ & $1.233 \pm 0.752$ & 0.5863 \\
\hline p-value & $1-3: 0.1213$ & $1-3: 0.0007$ & $1-6:<0.0001$ \\
& $1-6: 0.0003$ & $3-6: 0.0056$ \\
\hline
\end{tabular}

$\mathrm{P}(<0.05)$.

fed was (Table 4) $2.764 \pm 2.441 \mathrm{mg} / \mathrm{l}, 1.168 \pm 0.000 \mathrm{mg} / \mathrm{l}$ and $0.705 \pm 0.173 \mathrm{mg} / \mathrm{l}$ successively in $1^{\text {st }}, 3^{\text {rd }}$ and $6^{\text {th }}$ month after birth, p-value showed a significant difference between the zinc concentration in breast milk between the $1^{\text {st }}$ and $3^{\text {rd }}$ month $(\mathrm{p}=0.0392)$ and between 1 and 6 month after birth $(p=0.0057)$. Regarding the exclusively breast fed mothers with LBW babies, the zinc concentration in breast milk was $2.457 \pm 1.408 \mathrm{mg} / \mathrm{l}, \quad 1.662 \pm 0.552 \mathrm{mg} / \mathrm{l}$ and $0.955 \pm$ $0.598 \mathrm{mg} / \mathrm{l}$ successively in $1^{\text {st }}, 3^{\text {rd }}$ and $6^{\text {th }}$ month after birth, $p$-value showed a significant difference between the zinc concentration in breast milk in the $1^{\text {st }}$ and $3^{\text {rd }}$ month $(\mathrm{p}=0.0001), 1^{\text {st }}$ and $6^{\text {th }}$ month $(\mathrm{p}<0.0001)$ and between $3^{\text {rd }}$ and $6^{\text {th }}$ month after birth $(p=0.0063)$. However there was no significant difference in breast milk concentration between mothers with NBW babies and mothers with LBW babies in $1^{\text {st }}, 3^{\text {rd }}$ and $6^{\text {th }}$ month after birth.

\section{Kinetic of Zinc Concentration in Breast Milk According to Babies' Age}

Based on the Kenneth Brown study in 2009 [10]: the amount of zinc ( $\mathrm{mg} / \mathrm{I})$ in breast milk and baby`s age, we can develop a mathematical equation to our own population (Figure 2). the data were normalized by logarithmic transformation: Ln [Zinc] $=0.960-$ $0.161^{*} \operatorname{Ln}(a ̂ g e)-0.187^{*} \operatorname{Ln}(a ̂ g e)^{2}$. This shows that if we have babies age, we can calculate the amount of available zinc in breast milk.

\section{Test the Reliability of our Equation with Brown's Models}

In order to use the distribution of zinc concentration in breast milk according to babies age model for our population, we conducted a comparison of results obtained by the two models.

Table 5 shows that there is not a significant difference between the two equations. Our equation is acceptable and usable for our population.

Model 1: Morocco.

$$
\operatorname{Ln}[\text { Zinc }]=0.960-0.161^{*} \operatorname{Ln}(\text { age })-0.187^{*} \operatorname{Ln}(\text { age }) 2
$$

Model 2: K. Brown et al. (2009) [10]. Focus on a synthesis of 33 international studies.

$$
\operatorname{Ln}[\text { Zinc }]=0.975-0.501^{*} \operatorname{Ln}(\text { age })-0.063^{\star} \operatorname{Ln}(\text { age }) 2
$$

Table 4: Zinc Concentration (mg/l) in Breast Milk for Exclusively Breast Feed Mothers with NBW and LBW Babies During 6 Month After Birth $(\mathrm{n}=32)$

\begin{tabular}{|c|c|c|c|c|}
\hline \multirow{2}{*}{} & \multicolumn{4}{|c|}{ Zinc in breast milk (mg/l) } \\
\cline { 2 - 5 } & \multicolumn{2}{|c|}{ Mothers with NBW babies $(\mathrm{n}=\mathbf{2 0})$} & \multicolumn{2}{c|}{ Mothers with LBW babies $(\mathrm{n}=12)$} \\
\cline { 2 - 5 } & Exclusively breast feed & Non exclusively breast feed & Exclusively breast feed & Non exclusively breast feed \\
\hline \hline 1 month & $2.764 \pm 2.441$ & $2.657 \pm 1.116$ & $2.457 \pm 1.408$ & $2.560 \pm 0.712$ \\
\hline 3 month & $1.168 \pm 0.000$ & $2.110 \pm 0.694$ & $1.662 \pm 0.552$ & $1.805 \pm 0.739$ \\
\hline 6 month & $0.705 \pm 0.173$ & $1.183 \pm 0.477$ & $0.955 \pm 0.598$ & $1.263 \pm 0.769$ \\
\hline p-value & $1-3: P=0.0392$ & $1-3: P=0.1465$ & $1-3: P=0.0048$ & $1-3: P=0.0001$ \\
& $1-6: P=0.0057$ & $1-6: P=0.0002$ & $3-6: P<0.0001$ & $1-6: P<0.0001$ \\
& $3-6: P=0.1130$ & $3-6: P=0.0006$ & $3-6: P=0.0063$ \\
\hline
\end{tabular}

$\mathrm{P}(<0.05)$. 


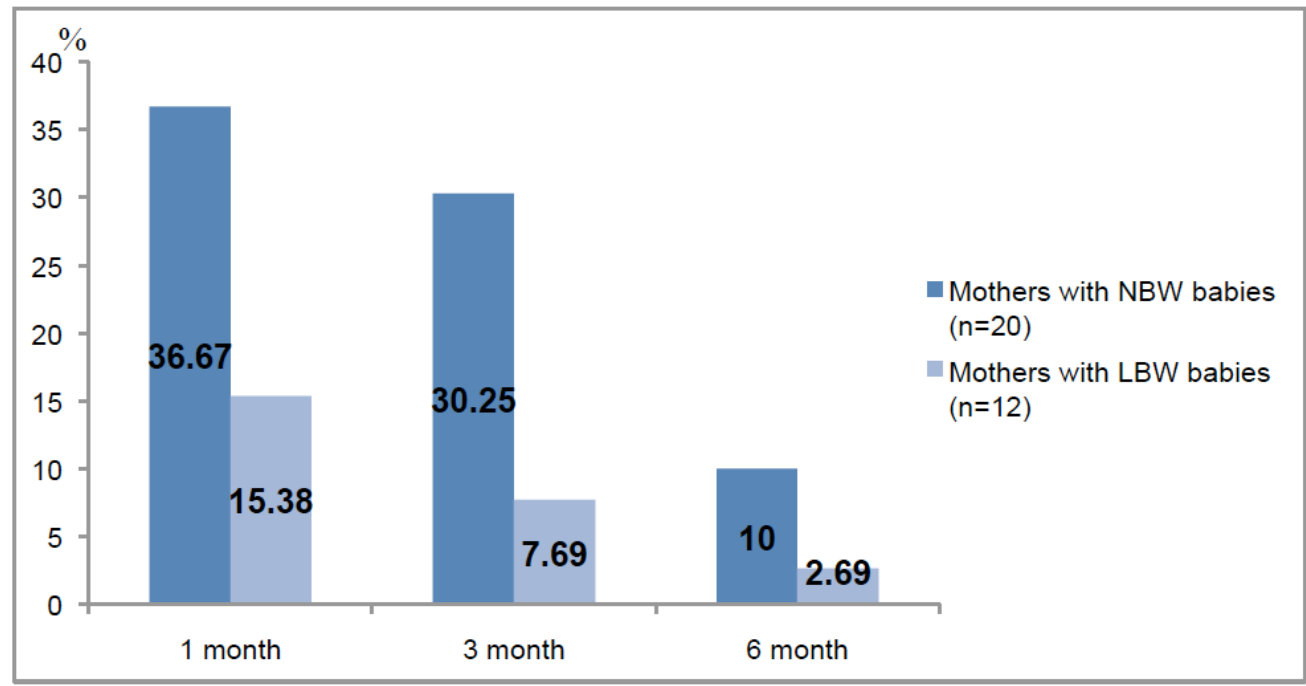

Figure 1: The rate of zinc ( $\mathrm{mg} / \mathrm{I})$ in milk by mode of lactation.

$$
\text { Ln (breastmilk [zinc]) (mg/L) }
$$

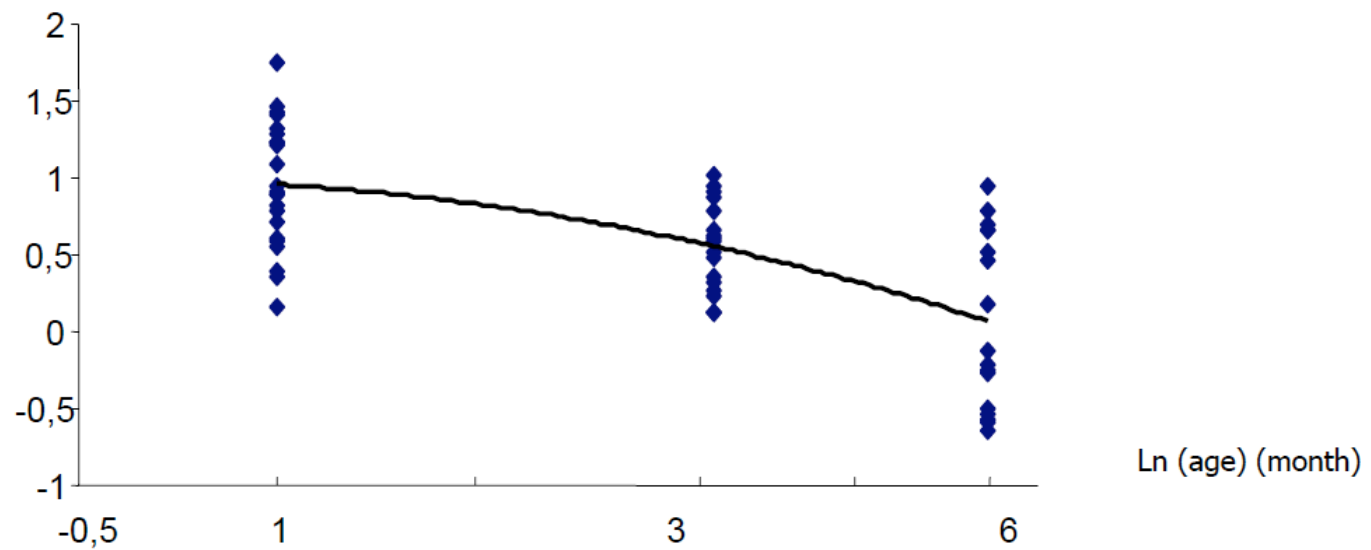

$$
\operatorname{Ln}[\text { Zinc }]=0.960-0.161 * \operatorname{Ln}(\text { age })-0.187 * \operatorname{Ln}(\text { age })^{2}
$$

Figure 2: Distribution of zinc concentration in breast milk according to babies' age after mathematical transformations of data.

\begin{tabular}{|c|c|c|c|c|}
\hline 3 month & 1.74 & 1.45 & 1.33 & 0.12 \\
\hline
\end{tabular}

Table 5: Comparison of Experimental Data and those Obtained After the Application of the Two Models

\section{DISCUSSION}

The amount of zinc in breast milk is generally regarded as sufficient to cover the increasing zinc demands infants [11]. However, this is not well investigated where stores zinc may be compromised in babies with low birth weight (LBW) who are born with low stores of zinc [12]. Breast milk zinc concentration 
declines rapidly during the first few months postpartum and more slowly thereafter. It is the important source of highly bioavailable zinc during this period of life and may be adequate as the sole source of zinc for exclusively breastfed term infants until $\sim 6$ months [10]. In Our study the results showed that zinc level decreased with increasing babies' age. Zinc concentrations in the breast milk of mothers who delivered LBW babies are slightly low compared with mothers who delivered NBW. We found that zinc breast milk concentration for mothers with NBW babies was $2.674 \pm 1.239 \mathrm{mg} / \mathrm{l}, 2.037 \pm 0.714 \mathrm{mg} / \mathrm{l}$ and $1.109 \pm 0.474$ $\mathrm{mg} / \mathrm{l}$ successively in $1^{\text {st }}, 3^{\text {rd }}$ and $6^{\text {th }}$ month after birth. Regarding the mothers with LBW babies the zinc concentration in breast milk was $2.524 \pm 0.992 \mathrm{mg} / \mathrm{l}$, $1.754 \pm 0.673 \mathrm{mg} / \mathrm{l}$ and $1.233 \pm 0.752 \mathrm{mg} / \mathrm{l}$ successively in $1^{\text {st }}, 3^{\text {rd }}$ and $6^{\text {th }}$ month after birth. However there was no significant difference in breast milk concentration between mothers with NBW babies and mothers with LBW babies in $1^{\text {st }}, 3^{\text {rd }}$ and $6^{\text {th }}$ month after birth. Our results show that during the sixth months after birth, there was not an impact of the zinc amount in breast milk on the babies' weight. Therefore the LBW babies recovered their weight quickly and they did not suffer from any form of malnutrition. Sellen DW and Piletz JE [12-13] found similar results. Breastfeeding is the best method of nutrition for infants. The World Health Organisation (WHO) recommends breastfeeding as the exclusive method of nutrition for newborns and infants at least up to 6 months of age [14]. In Morocco, there has been an alarming decline in the practice of exclusive breastfeeding (EB) over the past fifteen years. Based on questionnaire analysis, the proportion of exclusive breastfeeding until 6 months is currently around $15 \%$ [15]. Our study revealed that the rate of NBW babies who were exclusively breastfed was $36.67 \%, 30.25 \%$ and $10 \%$ successively in $1^{\text {st }}, 3^{\text {rd }}$ and $6^{\text {th }}$ month after birth. For LBW babies the rate of exclusively breastfed babies was $15.38 \%, 7.69 \%$ and $2.69 \%$ successively in $1^{\text {st }}, 3^{\text {rd }}$ and $6^{\text {th }}$ month after birth. In other countries such as Cambodia (60.1\%), Germany (45\%), Indonesia (39\%), Syria (38\%) and Switzerland (32\%) [16-17], exclusive breastfeeding is practiced by a large proportion of women. Zinc concentration $(\mathrm{mg} / \mathrm{l})$ in breast milk for mothers with NBW babies who are exclusively breastfed was $2.764 \pm 2.441 \mathrm{mg} / \mathrm{l}, 1.168 \pm 0.000 \mathrm{mg} / \mathrm{l}$ and $0.705 \pm 0.173$ $\mathrm{mg} / \mathrm{l}$ successively in $1^{\text {st }}, 3^{\text {rd }}$ and $6^{\text {th }}$ month after birth. For mothers with LBW babies, the zinc concentration in breast milk was $2.457 \pm 1.408 \mathrm{mg} / \mathrm{l}, 1.662 \pm 0.552 \mathrm{mg} / \mathrm{l}$ and $0.955 \pm 0.598 \mathrm{mg} / \mathrm{l}$ successively in $1^{\text {st }}, 3^{\text {rd }}$ and $6^{\text {th }}$ month after birth. However there was no significant difference in breast milk concentration between mothers with NBW babies and mothers with LBW babies in $1^{\text {st }}, 3^{\text {rd }}$ and $6^{\text {th }}$ month after birth. This is confirmed by the study of K. Brown [18] P. Hemalatha [19] A. Higashi [20] PB. Moser [21]. The amount of zinc transferred in breast milk to partially breastfed infants less than 6 months of age is approximately $15 \%$ less than that described above for exclusively breastfed infants, because of the smaller volumes of milk consumed by partially breastfed infants [10]. The age-related pattern of change in milk zinc intakes is similar for both groups of infants. Ni environmental or constitutional variables consistently affected zinc concentration or its rate of decrease in breast milk. Stage of lactation is the only variable associated with important changes in milk zinc concentrations [22]. On the other hand, several longitudinal studies have found greater variability in milk zinc concentration between women than within women [23], indicating that individual women have characteristic levels of zinc in their milk, possibly because of genetic factors influencing zinc transport to or within the mammary gland. Based on the Kenneth Brown study in 2009 [10]: the amount of zinc (mg / I) in breast milk and baby's age, we can developed a mathematical equation to our own population. The data were normalized by logarithmic transformation: Ln [Zinc] $=0.960-0.161^{*} \operatorname{Ln}($ âge $)-0.187^{*} \operatorname{Ln}(\text { âge })^{2}$. This shows that if we have babies age, we can calculate the amount of available zinc in breast milk. Our equation was tested and used.

\section{CONCLUSION}

Zinc concentration in breast milk for both groups of mothers is within normal range and decreases with the age of the babies. Therefore the LBW babies recovered their weight quickly and they did not suffer from any form of malnutrition. The rate of exclusively breast feeding babies is very low; there has been an alarming decline in the practice of exclusive breastfeeding in Morocco. The predicted model of zinc concentration in human milk was developed and tested.

\section{ACKNOWLEDGEMENTS}

The financial and technical support of the International Atomic Energy Agency is gratefully acknowledged. We are grateful to the entire staff for their kind collaboration.

We are also indebted to the mothers of the infant who agreed to participate in this study. 


\section{REFERENCES}

[1] Brown KH, Rivera JA, Bhutta Z, Gibson RS, King JC, Lönnerdal $B$, et al. Assessment of the risk of zinc deficiency in populations and options for its control. Food Nutr Bull 2004; 25(1 suppl 2): S99-203.

[2] de Benoist B, Darnton-Hill I, Davidsson L, Fontaine O, Hotz C. Conclusions of the joint WHO/UNICEF/IAEA/IZiNCG interagency meeting on zinc status indicators. Food Nutr Bull 2007; 28: S480-S79.

[3] Hess SY, Brown K. Impact of zinc fortification on zinc nutrition. Food Nutr Bull 2009; March.

[4] Black RE, Allen LH, Bhutta ZA, Caulfield LE, de Onis M, Ezzati M, et al. Maternal and child undernutrition: Global and regional exposures and health consequences. Lancet 2008; 371: 243-60. http://dx.doi.org/10.1016/S0140-6736(07)61690-0

[5] Bahl L, Chaudhuri LS, Pathak RM. Study of serum zinc in neonates and their mothers in Shimla hills (Himachal Pradesh). Indian J Pediatr 1994; 61: 571-5. http://dx.doi.org/10.1007/BF02751721

[6] Nakamori M, Ninh NX, et al. Nutritional Status of Lactatting Mothers and Their Breast Milk Concentration of Iron, Zinc and Copper in Rural Vietnam. J Nutr Sci Vitaminol 2009; 55: 338-45.

http://dx.doi.org/10.3177/jnsv.55.338

[7] WHO. Complementary feeding of young children in developing countries: a review of current scientific knowledge. Geneva, World Health Organization 1998.

[8] Lamounier JA, Danelluzzi JC, Vannucchi H. Zinc concentrations in human milk during lactation: a 6-month longitudinal study in southern Brazil. J Trop Pediatr 1989; 35 : 31-4. http://dx.doi.org/10.1093/tropej/35.1.31

[9] Choua G. EL Kari K, EL Haloui N, Slater C, Aguenaou H. Mokhtar N. Quantitative assessment of breastfeeding practices and maternal body composition in Moroccan lactating women during six months after birth using stable isotopic dilution technique. Int J Mater Child Health 2013; 1(3): 45-50. DOI: 10.12966/ijmch.09.01.2013.

[10] Brown KH, Engle-Stone R, Krebs NF, Peerson JM. Dietary intervention strategies to enhance zinc nutrition: Promotion and support of breastfeeding for infants and young children. Food and Nutrition Bulletin, vol. 30, no. 1 (supplement) (c) 2009, The United Nations University.

[11] Elizabeth KE, Krishnan V, Vijayakumar T. Umbilical cord blood nutrients in low birth weight babies in relation to birth weight and gestational age. Indian J Med Res 2008; 128: 128-33.

[12] Sellen DW. Evolution of Infant and Young Child Feeding: Implications for Contemporary Public Health. Ann Rev Nutr 2007; 27: 123-48.

http://dx.doi.org/10.1146/annurev.nutr.25.050304.092557

[13] Piletz JE. Ganschow REls acroderrnatitis enteropathica related to the absence of zinc binding ligand in bovine milk? Am J Clin Nutr 1979; 32(2): 275-77.

[14] WHO. Global strategy for infant and young child feeding. WHO Library Cataloguing-in-Publication Data, Geneva 2003.

[15] Enquête Nationale à Indicateurs Multiples et Santé des Jeunes: ENIMSJ 2006-2007, 2008. Maroc. http://srvweb. sante.gov.ma/Publications/Etudes_enquete/Documents/ENI MSJ_\%20Rapport\%20final.pdf

[16] Senarath U, Dibley MJ, Agho KE. Factors Associated With Nonexclusive Breastfeeding in Five East and Southeast Asian Countries: A Multilevel Analysis. J Hum Lact 2010; 26(3): 248-57. http://dx.doi.org/10.1177/0890334409357562

[17] WHO. The world health report 2000 - Health systems: improving performance. ISBN 924156198 X. France 2000.

[18] Brown KH, Dewey KG, Allen LH. Complementary feeding of young children in developing countries: A review of current scientific knowledge. Geneva: World Health Organization 1998.

[19] Hemalatha P, Bhaskaram P, Kumar PA, Khan MM, Islam MA. Zinc status of breastfed and formula-fed infants of different gestational ages. J Trop Pediatr 1997; 43: 52-4. http://dx.doi.org/10.1093/tropej/43.1.52

[20] Higashi A, Ikeda T, Uehara I, Matsuda I. Zinc and copper contents in breast milk of Japanese women. Tohoku J Exp Med 1982; 137: 41-7. http://dx.doi.org/10.1620/tjem.137.41

[21] Moser PB, Reynolds RD. Dietary zinc intake and zinc concentrations of plasma, erythrocytes, and breast milk in antepartum and postpartum lactating and nonlactating women: A longitudinal study. Am J Clin Nutr 1983; 38: 101-8.

[22] Leotsinidis M, Alexopoulos A, Kostopoulou-Farri E. Toxic and essential elements in human milk from Greek lactating women. Association with dietary habits and other factors. Chemosphere 2005; 61: 238-47. http://dx.doi.org/10.1016/j.chemosphere.2005.01.084

[23] Krebs NF, Reidinger CJ, Hartley S, Robertson AD, Hambidge KM. Zinc supplementation during lactation: Effects on maternal status and milk zinc concentrations. Am J Clin Nutr 1995; 61: 1030-6.

Received on 01-02-2014

Accepted on 25-02-2014

Published on 10-03-2014

\section{http://dx.doi.org/10.6000/1929-4247.2014.03.01.6}

(C) 2014 Choua et al.; Licensee Lifescience Global.

This is an open access article licensed under the terms of the Creative Commons Attribution Non-Commercial License (http://creativecommons.org/licenses/by-nc/3.0/) which permits unrestricted, non-commercial use, distribution and reproduction in any medium, provided the work is properly cited. 